\title{
Soil Degradation and Socioeconomic Systems' Complexity: Uncovering the Latent Nexus
}

\author{
Filippo Gambella ${ }^{1}{ }^{\oplus}$, Giovanni Quaranta ${ }^{2}{ }^{(}$, Nathan Morrow $^{3}{ }^{\circledR}$, Renata Vcelakova ${ }^{4}$, Luca Salvati ${ }^{5}$, \\ Antonio Gimenez Morera ${ }^{6}$ and Jesús Rodrigo-Comino $7,8, *(\mathbb{0}$
}

1 Department of Agriculture, University of Sassari, Viale Italia 39, I-07100 Sassari, Italy; gambella@uniss.it

2 Mathematics, Computer Science and Economics Department, University of Basilicata, Viale dell'Ateneo Lucano, I-85100 Potenza, Italy; giovanni.quaranta@unibas.it

3 School of Public Health and Tropical Medicine, Tulane University, New Orleans, LA 70112, USA; nmorrow@tulane.edu

4 Global Change Research Institute of the Czech Academy of Sciences, Lipová 9, CZ-37005 České Budějovice, Czech Republic; vcelakova.r@czechglobe.cz

5 Department of Economics and Law, University of Macerata, Via Armaroli 43, I-62100 Macerata, Italy; luca.salvati@unimc.it

6 Departamento de Economia y Ciencias Sociales, Universitat Politècnica de València, Cami de Vera S/N, 46022 València, Spain; angimo1@doctor.upv.es

7 Department of Physical Geography, University of Trier, 54296 Trier, Germany

8 Soil Erosion and Degradation Research Group, Department of Geography, Valencia University, Blasco Ibàñez, 28, 46010 Valencia, Spain

* Correspondence: jesus.rodrigo@uv.es

Citation: Gambella, F.; Quaranta, G.; Morrow, N.; Vcelakova, R.; Salvati, L.; Gimenez Morera, A.;

Rodrigo-Comino, J. Soil Degradation and Socioeconomic Systems' Complexity: Uncovering the Latent Nexus. Land 2021, 10, 30. https:/ / doi.org/10.3390/land10010030

Received: 2 December 2020 Accepted: 26 December 2020 Published: 1 January 2021

Publisher's Note: MDPI stays neutral with regard to jurisdictional clai$\mathrm{ms}$ in published maps and institutional affiliations.

Copyright: (C) 2021 by the authors. Licensee MDPI, Basel, Switzerland. This article is an open access article distributed under the terms and conditions of the Creative Commons Attribution (CC BY) license (https:// creativecommons.org/licenses/by/ $4.0 /)$.
Abstract: Understanding Soil Degradation Processes (SDPs) is a fundamental issue for humankind Soil degradation involves complex processes that are influenced by a multifaceted ensemble of socioeconomic and ecological factors at vastly different spatial scales. Desertification risk (the ultimate outcome of soil degradation, seen as an irreversible process of natural resource destruction) and socioeconomic trends have been recently analyzed assuming "resilience thinking" as an appropriate interpretative paradigm. In a purely socioeconomic dimension, resilience is defined as the ability of a local system to react to external signals and to promote future development. This ability is intrinsically bonded with the socio-ecological dynamics characteristic of environmentally homogeneous districts. However, an evaluation of the relationship between SDPs and socioeconomic resilience in local systems is missing in mainstream literature. Our commentary formulates an exploratory framework for the assessment of soil degradation, intended as a dynamic process of natural resource depletion, and the level of socioeconomic resilience in local systems. Such a framework is intended to provide a suitable background to sustainability science and regional policies at the base of truly resilient local systems.

Keywords: demographic dynamics; rural districts; resilience; desertification risk

\section{Introduction}

Soil degradation reflects the joint action of ecological factors and socioeconomic forces at multiple geographical scales [1,2]. Assumed as a biophysical and socioeconomic process that implies a progressive deterioration of soils, land degradation has reached an increasingly significant speed in modern times, with dynamics that increasingly involve integrated aspects encompassing the broad range of socio-economic issues [3,4]. A major role is played by climate change, the increase of human pressure, and the progressive abandonment of rural areas, that fuels a progressive degradation of natural resources including soil, water, and landscapes [5,6]. Although soil degradation is regarded as an almost reversible process, leaving the underlying forces uncontrolled leads to irreversible 
forms of desertification [7,8]. Desertification is the terminal stage of such (more or less) reversible processes of soil degradation. While the "desertification" notion implies landscape scenarios resembling deserts, desertified areas are mostly non-desert, arid land, where soils are heavily impoverished but where there is still vegetation and life [9]. These areas could be subject to progressive degradation phenomena that alter the physical and economic potential of the soils, and which therefore prevent, alter, or reduce the soil's ability to produce [10].

In this regard, the latest (and likely worst) stages of soil degradation include a rapid decline in ecosystem services [11-13]. At the same time, it is well-known how soil degradation gives rise to multiple economic influences, altering socio-demographic functions, and hampering sustainable development paths, especially in ecologically fragile districts [14-16]. Reciprocally, the socioeconomic developmental path of any given local system may influence the level of soil degradation, producing a sort of downward spiral that should be effectively governed with appropriate mitigation strategies. Responding to these basic socio-ecological issues, human action may address complex problems associated with soil degradation and desertification risk, by, for example, promoting socio-environmental well-being in affected (or vulnerable) regions [17-24]. Linking soil degradation and desertification risk with climate change is certainly appropriate. However, climate change is not the only actor behind desertification. Drought and aridity are clearly a basic component of a desertified landscape, but they are not sufficient pre-requisites to trigger desertification $[25,26]$. An area at risk of desertification implies an interaction, often complex, between different agents that impact the landscape, including bio-physical agents, and more precisely climate, global warming, water scarcity, but also wildfires, overgrazing, and general processes adjusted to the overall human pressure $[27,28]$. These processes add to population density, infrastructures, land consumption, and other environmental pressures [29].

In these regards, we focused on the driving forces and the economic, social, and ecological consequences of soil degradation. While, for instance, agricultural production decreases with soil degradation, other economic sectors are also affected by desertification risk, for example, industrial sectors needing water supplies in places where there is a water shortage, or mass tourism and its ecological footprint on fragile ecosystems [30,31]. The consequences of soil degradation are not exclusively of economic or ecological nature, being eminently social: for instance, "climatic" migrations, that is, long-haul people movements that gradually strengthen because conditions of drought and aridity advance, which prevent the possibility of living and producing in places that were previously productive and now are partially or totally derelict. In these regards, land take and soil consumption are problems of particular interest because they involve fragile territories but also economically strong districts.

However, while a land take is certainly a very important element that increases soil degradation, multiple factors are needed to trigger a desertification process. Additional issues hampering soil conservation are considered prominent in such a case and include (i) the intrinsic mismatch between positive and normative targets in affected regions, (ii) a partial (or complete) lack of context-specific solutions to soil degradation, and (iii) incomplete communication of local levels with upper levels of governance [32-34]. These issues paralleled a latent weakness in development planning and programs, not only in emerging countries but also in some advanced economies, together with the partial lack of extensive exercises of soil vulnerability assessment over continents or ecological regions [35-38]. These research gaps resulted in weak support for effective policymaking at regional and continental levels, for example, [39-42]. Local system complexity analyzes the intrinsic relationship between soil degradation and the socio-economic sphere, a particularly hard task requiring more specific approaches oriented toward the integration of complex system thinking with sustainability science and regional planning [43-46].

Models referring to Complex Adaptive Systems (CAS) vision seem to be particularly appropriate when analyzing local systems' dynamics over time and space [47-49]. 
When investigating the intrinsic relationship between soil degradation and local systems' performances [50-52], a CAS approach allows a refined analysis of local development supporting the design of appropriate spatial planning and economic measures aimed at preserving (and hopefully enhancing) the system's resilience [53-55]. With this perspective in mind, "socioeconomic resilience" focuses on the ability of a regional economy to preserve the pre-existing state (assumed to be in a form of "dynamic equilibrium") under exogenous shocks. This perspective assumes resilience as a basic property associated with the extent to which a socioeconomic system is capable of returning to its preceding status (e.g., maintaining a steady-state growth rate of output, employment, or population) after a shock. In these regards, the concept of resilience therefore depends on socio-environmental factors exerting a specific impact over a given territory. Our commentary integrates two socio-environmental visions dealing with (i) soil degradation (incorporating a specific issue dealing with ecosystem's services) and (ii) local system's complexity (mixing issues of system's sustainability—basically referring to socioeconomic resilience-with the final aim at achieving a better comprehension of local systems under complex socioeconomic dynamics) and ecological problems in Mediterranean Europe, a bio-climatic region with intense sensitivity to soil degradation. Understanding sustainability vs. resilience conflicts is a central issue in the assessment of land resources [52-57].

The key to truly sustainable development is the enhancement of basic conditions for the resilience of local systems [58-60], and the capacity to buffer unwanted or unpredictable changes [61-63]. In this regard, sustainable and resilient paths of local development are regarded as intimately linked notions [64-66]. Based on these premises, we provide a fresh vision of local development vis à vis environmental issues, exploring the intrinsic relationship between a complex phenomenon such as soil degradation and the evolving local systems in a mixed sustainability-resilience perspective. The article introduces an operational definition of soil degradation in local systems, providing a refined analysis of the latent linkage between ecosystem services (mainly focusing on climate, soil, and vegetation dimensions) and environmental deterioration. A practical approach to soil degradation, sustainable development, and socioeconomic resilience was subsequently delineated. Finally, a coherent assessment of socioeconomic resilience in complex local systems was illustrated using different research dimensions, proposing an integrated view to regional planning in light of sustainable development, and enhancing the resilience of complex socioeconomic systems $[10,67,68]$.

\section{A Brief Overview of "Soil Degradation" Processes}

The inherent complexity of soil degradation is illustrated in Figure 1, which highlights the intimate interconnections between multiple research dimensions and the underlying drivers of change. In particular, this figure clarifies the close relationship that exists between the basic ecological context and the surrounding socioeconomic forces as other authors highlighted over the world [69-72]. This interpretation of soil degradation as a complex issue justifies an integrated approach to the analysis of the relationship between soil degradation (seen as an exquisitely environmental problem) and socioeconomic forces [73,74]. By integrating different research and analysis dimensions, a coherent analysis of such a relationship requires considering sustainability and resilience together in a single operational approach $[27,75-77]$. Since soil degradation is eminently a human issue, assumptions about the relationship between landscape degradation and soil productivity (e.g., the decline in soil organic matter, land capacity, and economic viability of cropping systems), clearly reflect human-nature interactive processes in both advanced economies and emerging countries $[78,79]$. Being in a strict relationship with any soil degradation process, economic organization of regions, social inequalities, and political interventions should be addressed in light of the theoretical framework of sustainable development $[80,81]$. 


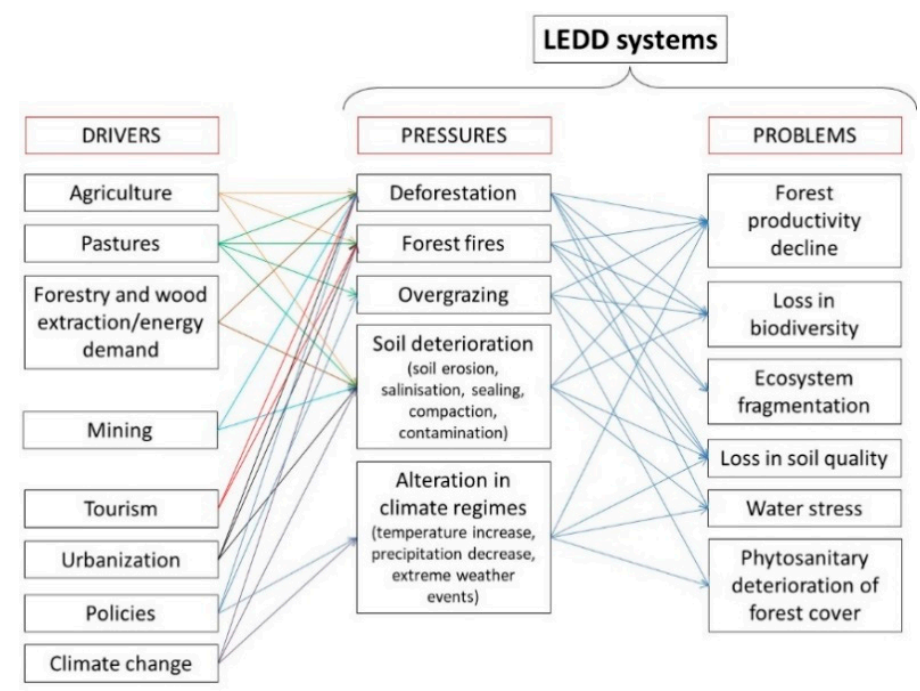

Figure 1. A common framework that illustrates the intrinsic complexity of local systems exposed to "soil, Land and Ecosystem Degradation and Desertification risk" (LEDD).

Taken as one of the most relevant socioeconomic forces shaping the environmental quality and landscape characteristics, population growth has demonstrated to exert direct and indirect consequences on soil degradation, being likely the most important driver of change in local systems experiencing soil degradation as some authors documented for some affected countries [82-86]. Reflecting population growth, human pressure can be linked to (i) an intense relocation of population along the coastal rim, because of tourism intensification and/or industrial concentration, (ii) increasing population (and economic activities) concentration in metropolitan regions, and (iii) a progressive scattering of highimpact industrial activities in flat and most accessible districts [87-92]. Socioeconomic aspects take part in soil degradation: earlier studies have outlined how soil degradation hurts economic dynamics and performances [93-97]. Since there is little empirical evidence documenting degradation-driven economic losses, long-term socioeconomic planning is a particularly hard task in ecological contexts with largely fluctuating conditions [98-101].

Being constrained together by ecological contexts and socioeconomic backgrounds [93], an appropriate land management system is aimed at (i) conserving ecological functions, (ii) increasing the efficiency of ecosystem services, and (iii) promoting cohesive territories from socioeconomic and biophysical perspectives. Based on the key dimensions illustrated in Figure 2, high levels of functional diversification in socio-environmental systems depend on different services [102,103] related to climate, soil quality, vegetation, and land use, together with specific socioeconomic assets. These dimensions are key to understanding the extent and severity of local SDPs. Identification of spatial influences and direction of change in such dimensions (and, especially, climate, soil, and vegetation quality) offers several options for regional planning [48,104-107]. Spatially explicit approaches provide new opportunities to design influential approaches investigating those linkages among social and biophysical processes that are essential to regional planning [52]. In this regard, multi-disciplinary approaches to soil degradation are increasingly required in any effective planning strategy assessing the local system's complexity [96-99]. 

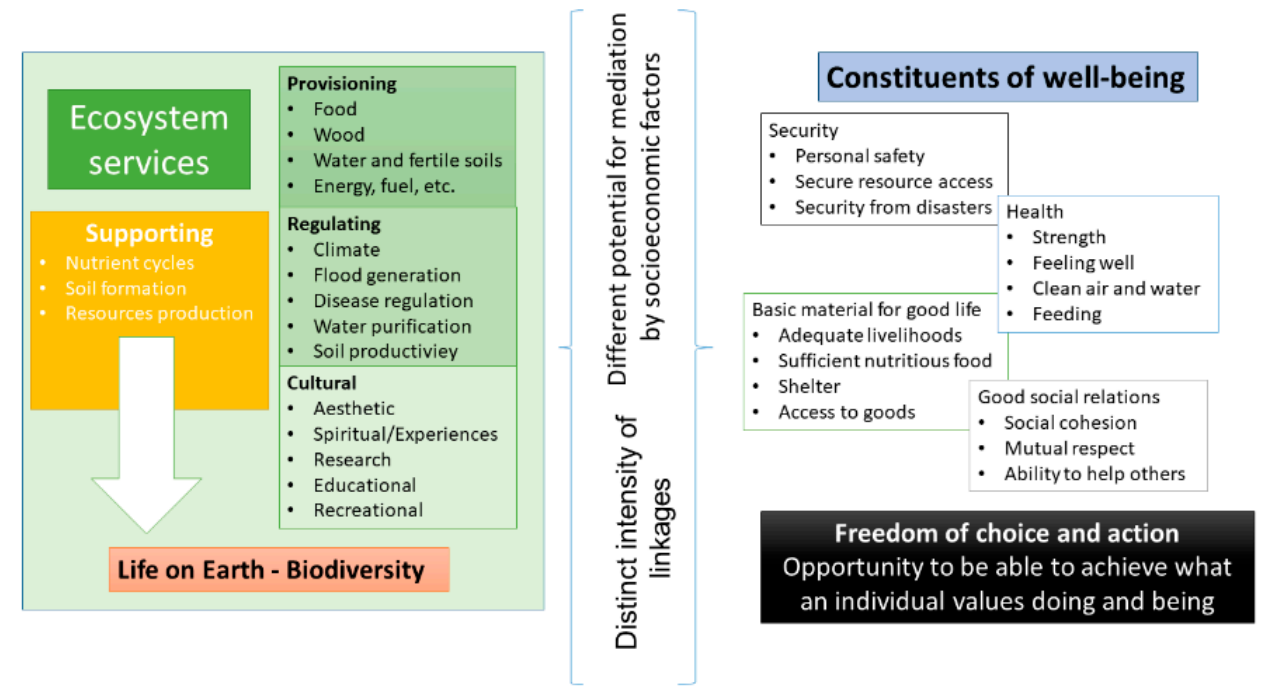

Figure 2. Reinterpretation of the intrinsic linkages between Ecosystem Services and Human Wellbeing (derived from the Millennium Ecosystem Assessment: Ecosystems and human well-being. Volume 1: current state and trends. Washington, DC. Island Press, 2005).

Considering together climate, soil, and vegetation quality, the ESA (Environmentally Sensitive Area) approach (Figure 3) estimates the level of land vulnerability to degradation which affects a specific area [95]. A comprehensive analysis of such dimensions provides detailed information on key factors of soil degradation including vegetation, climate, soil, and land management [96]. The ESA framework emphasizes (i) political, social, demographic, and economic processes leading to soil degradation, (ii) the inherent consequences for landscapes and environments at large, and (iii) the possible response that societies can implement with the final objective at contrasting processes of land degradation and, ultimately, desertification risk [97].

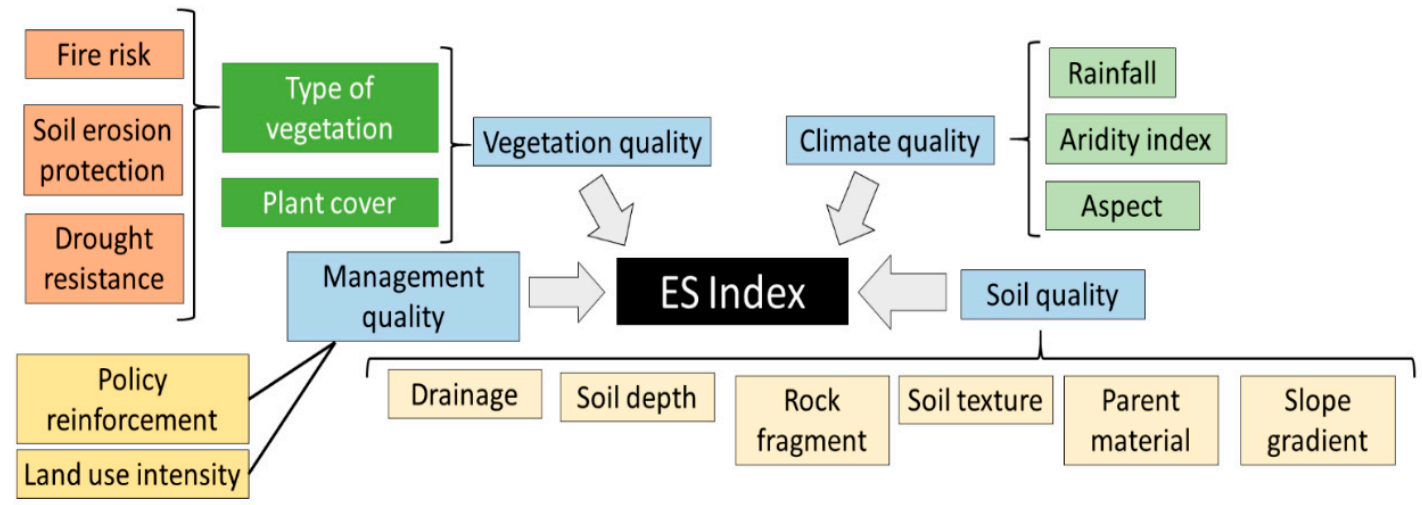

Figure 3. A graphical workflow of input variables and partial indicators adopted in the ESA (Environmentally Sensitive Area) framework to estimate sensitivity to soil degradation.

The ESA approach identifies a reference framework applicable to different ecological and socioeconomic contexts under the following assumptions: (i) input variables are reasonably simple to operationalize, statistically robust and widely applicable; (ii) variables' selection reflects both the specific information context (i.e., the intrinsic relationship with "soil degradation" and "desertification risk" dimensions), and the easiness in data collection, comparison with external data sources and updates; and (iii) the overall information system is enough adaptable to accommodate new variables (or refined informative layers) that may improve the precision of the estimates. The elementary data layers are combined using 
simplified algorithms (geometric mean) into quality (partial) indicators for soil, climate, vegetation, and land management (Table 1 ).

Table 1. Input variables for ESA frameworks assessing land degradation and the related sources.

\begin{tabular}{|c|c|c|}
\hline Quality & Layer & Source \\
\hline Soil & $\begin{array}{c}\text { Parent material, Rock } \\
\text { Fragments, Soil Depth, Slope } \\
\text { Angle, Drainage, Soil Texture }\end{array}$ & $\begin{array}{l}\text { Published data and field } \\
\text { samplings }\end{array}$ \\
\hline Climate & Rainfall, Aspect, Aridity index & $\begin{array}{l}\text { Published data, field } \\
\text { samplings, and DEM }\end{array}$ \\
\hline Vegetation & $\begin{array}{c}\text { Fire risk, Erosion protection, } \\
\text { Drought resistance, Plant } \\
\text { cover }\end{array}$ & Landsat TM \\
\hline Management & $\begin{array}{l}\text { Policy enforcements, Land use } \\
\text { intensity, population density }\end{array}$ & Statistical data \\
\hline
\end{tabular}

In the second step, the level of Environmental Sensitivity (ES) at each elementary analysis' unit (e.g., a cell, a polygon, a landscape) is evaluated combining the four partial indicators using the same algorithm (geometric mean):

$$
\mathrm{ES}_{\mathrm{ij}}=\left(\operatorname{Indicator}_{(1) \mathrm{ij}} * \operatorname{Indicator}_{(2) \mathrm{ij}} * \operatorname{Indicator}_{(3) \mathrm{ij}} * \operatorname{Indicator}_{(4) \mathrm{ij}}\right)^{1 / 4}
$$

where $i, j$ are rows and columns of an elementary spatial domain and $\operatorname{Indicator}(n)_{i j}$ is the related value for each dimension considered (individual variables, partial indicators). In the ESA framework, a major concern is to define soil deterioration considering the characteristic economic dimensions. An example of the intrinsic validity and vast applicability of the ESA framework for planning reasons-from local to global operational scales-is the worldwide maps of soil sensitivity to degradation and the related ecosystem's drivers of change provided by Ferrara et al. [98] at a very detailed spatial resolution and referring to a time period encompassing the 2010s. This approach integrates a decision support system based on a simplified land classification nomenclature with a refined analysis of ecosystem's functions involved in soil degradation processes, providing the necessary knowledge to any strategy of sustainable land management and regional planning oriented toward socio-ecological system's resilience [99-102].

\section{Soil Degradation, Sustainable Development, and Socioeconomic Resilience of Local Systems}

The notion of "sustainability", however vague it may seem, continues to aliment the idea that sustainability implies a quantifiable limit to economic growth. At the same time, sustainability is still understood as a call to action and therefore as a political process. In this perspective, the concept of sustainable development has been enriched and evolved substantially [103]. Starting from the "simple" but effective definition by the Bruntland report, such a notion consolidated in a holistic and integrated perspective, which has perhaps received its greatest inspiration and practical translation in the 2030 Agenda. In these regards, the Agenda 2030 redesigns the objectives for sustainable development, articulating them into specific targets. Avoiding any distinction between affluent and emerging countries, this strategy is an implicit contribution to the issue of spatially balanced development typical of the "sustainability" paradigm.

While the idea that sustainability is solely an "environmental" issue of concern has been definitively overcome, an integrated vision of the different dimensions of local development has been progressively established. However, the implementation of the Agenda is not an easy or obvious target. In response to this goal, the Sustainable Development Strategy of the 2030 Agenda provides a renewed global framework that strengthens the (often fragmented) path of sustainable development on a global scale, promoting environmental, economic, and social sustainability objectives in an integrated vision. A total of 169 
targets corresponding to the Millennium Development Goals aim at solving a wide range of problems concerning socio-economic development, such as poverty, hunger, health, education, climate change, gender equality, water, sanitation, energy, urbanization, and the environment, all being intrinsically connected with the specific issue of soil degradation. The Millennium Development Goals interpret the sustainability paradigm as an operational "umbrella" for local development, including and expanding the specific dimension of sustainability in multiple axes, and keeping the aspect of local sustainability of the core of this process.

In parallel with the general issue of sustainable development, local resilience has been investigated in relation to specific areas and background socioeconomic conditions, being intrinsically connected with complex environmental issues and dynamics, among which soil degradation and desertification risk are considered particularly relevant processes of change [108-110]. Understanding the intrinsic mechanisms underlying resilience-as well as other typical properties of local systems such as adaptability and transformabilityseems to be particularly appropriate in areas affected by land degradation. Such knowledge requires a complete investigation of social complexity (intended as the network of relations among different territorial actors) in desertification-prone districts [53]. In such contexts, the notion of "regional economic resilience" has been originally proposed to delineate the ability of an economic system to avoid being packed into a low-level equilibrium [105], promoting instead a (more or less rapid) transition toward a "better" equilibrium in a given district [49]. A comprehensive analysis of regional resilience requires a specific focus on (highly open and internally heterogeneous) systems' dynamics [106].

Contrasting linear visions of local development, a holistic perspective to complex systems would emphasize the intimate relationship among socioeconomic variables persisting over a long term and reflecting continuous regional growth and transformations, considering at the same time the political and socio-cultural institutions affecting this relationship's structure [35]. Economic systems can exhibit three types of responses to external shocks. First, systems may return to (or surpass) their preceding growth within a relatively short period ("economically resilient" districts). Second, systems might not have been thrown off their development path at all ("shock-resistant" districts). Third, systems result to be incapable to rebound and return to (or surpass) their previous "non-resilient" path [36].

\section{Assessing the Level of Socioeconomic Resilience in Local Systems}

Two dimensions are taken as significant when assessing how socioeconomic forces impact together with the resilience level of local communities and soil degradation processes [107]: (i) factors perturbing (alimenting or containing) soil degradation, mostly those associated with specific policies based on targeted subsidies, incentives or, more generally, external economic support; and (ii) factors related to how local communities may face (and mitigate) soil degradation. While being sparsely defined and measured only partially, the notion of "socioeconomic resilience" has growing importance in regional science and spatial planning [108]. Economically resilient and non-resilient economic systems are frequently identified and characterized examining their long-term dynamics and performances [109]. Criteria delineating (and quantifying the intensity of) an economic shock can take inspiration from a descriptive analysis of pre-shock and post-shock growth rates and the related levels of economic performance [110]. A region experiencing an external shock without meeting specific criteria is taken as "non-resilient" [111]. To implement a socioeconomic measure of resilience for a given local system, a series of issues should be addressed including: (i) what measure(s) is (are) most appropriate to assess socioeconomic performances (e.g., gross domestic product, value-added, employment, personal income and wealth), (ii) what spatial scale is more appropriate for such measure(s); (iii) what time scale is more effective for such measure(s); and, finally, (iv) what territorial scale should be considered for comparative analysis purposes (e.g., country average, regional/division average).

Assuming any spatial definition of a given socio-economic system as highly subjective, at least to some degrees, it is important to remember how local communities and the related 
economic space and geographical territory represent districts where people, money, goods, and services continuously cross any fixed boundary adopted, both administrative and functional [85]. Moreover, although a given socioeconomic system can be defined at a specific spatial scale, interactions with any other system can also occur continuously among all levels. In this regard, theoretical foundations of socioeconomic resilience are intrinsically linked with the "hegemonic" concept of sustainability, being explicitly defined as the interaction of three factors: (i) economic resistance to external shocks, (ii) social and cultural diversity (e.g., population size, skill mixing) and (iii) civic infrastructure [112]. Since socio-cultural diversity was occasionally estimated using data on lifestyle diversity [113], a summary indicator of socioeconomic resilience can be thus composed taking account of economic resilience, population density, and lifestyle diversity [114].

Actions allowing a region to benefit from positive shocks may further drive a stronger economic resilience, being capitalized in the case of a future shock [56]. These considerations lead to the basic assumption that the socioeconomic resilience of local systems strictly depends on the policy-induced ability of local communities to recover from (or adjust to) the negative impacts of adverse exogenous shocks [48]. In the specific perspective of soil degradation, a refined analysis of socioeconomic forces provides the necessary verification of the (in)ability of local communities to develop mitigation and adaptation policies responding to external shocks that include climate change, landscape transformations, and desertification risk. For instance, a lack of monetary resources and opportunities for additional/alternative funds is critical since it increases practically the probability of more intense, likely unsustainable use of natural resources, with, for example, land intensification having environmental side-effects [50].

Based on these premises, relevant dimensions estimating socioeconomic resilience of local systems include (i) macroeconomic stability, (ii) microeconomic market efficiency, (iii) good governance, and (iv) socio-demographic development [109]. A summary index of the level of socioeconomic resilience in local systems can be derived from simple (or more advanced) compositions of the four components mentioned above.

Macroeconomic stability relates to the interaction between aggregate demand and aggregate supply in a regional economic system [113]. Economic policy at all operational scales influences these dimensions, in turn acting as an honest proxy of economic resilience of local systems facing adverse shocks $[115,116]$. Earlier studies have preliminarily quantified the macroeconomic stability dimension considering three dimensions [106]: (i) the ratio of fiscal deficit to the gross domestic product; (ii) the government budget position, and (iii) an additional figure composing local unemployment and inflation rates [49]. These dimensions are associated with local resilience: for instance, when an economic system displays moderate or high levels of unemployment and inflation, the impact of adverse shocks would likely be particularly intense $[117,118]$. A measure of the ratio of the external debt to the gross domestic product may finally refine the resilience assessment because the adequacy of external policy may be estimated considering the weight of external debt on total product over a defined time window [119].

Microeconomic Market Efficiency is another possible aspect of socio-economic resilience. This measure evaluates the extent to which markets work competitively, freely, and efficiently across countries [38]. Finally, good governance is indispensable for an economic organization to function correctly and to be resilient. Relating to issues such as property rights, judicial independence, the impartiality of courts, the protection of intellectual property rights, military interference in the rule of law, political systems, and the integrity of the legal system should be considered. In this regard, socio-demographic development is an additional component of economic resilience, measurable in multiple ways depending on personal income (e.g., poverty line, long-term unemployment rate) or population structure/dynamics. 


\section{Concluding Remarks}

Resilience approaches try to combine ecological and socioeconomic dimensions of local systems, providing a suitable background to reconnect sustainable development with nature conservation strategies [119]. In such a view, local (either urban or rural) systems have assumed a crucial role in recent years. This vision is related to CAS thinking, being characterized by self-organization without a rigid (centralized or system-level) control. The role of non-linear development paths typical of regional economic systems is central for policymakers especially in landscape-driven approaches, complexity-led growth, and adaptive systems' thinking integrating ecological and socioeconomic approaches to territorial dynamics. In these regards, understanding non-linear landscape trajectories of development is a process-driven issue. Social interactions are unpredictable due to the intrinsic and multiple options characterizing human interactions. In this perspective, landscapes and the related local communities are intended as complex adaptive systems, whose complexity makes the future of regional development and spatial planning difficult to predict and organize. Since future development paths of complex socio-ecological systems are required to be together sustainable and resilient, a complex adaptive systems' approach to spatial planning and regional policy is reasonable and preferable in such conditions.

Crucial mechanisms through which policies influence environmental processes and, more specifically, soil degradation, are land-use structure, configuration, and change over time. In this direction, sector policies and subsidies often increase desertification problems. For instance, agricultural policies and subsidies focusing on single crops or products stimulate the conversion of traditional, sustainable multi-functional land-use systems into intensive productions like the mono-cultures that are less suitable and frequently not adjusted to the local natural and socio-cultural environments. In these regards, it cannot be demised how soil degradation leads to a (potentially significant) reduction in ecosystem functions and services of interest to humankind (e.g., biodiversity conservation). At the same time, regional planning oriented toward sustainability and resilience would protect local economies from potential shocks since this approach will enhance the overall level of resilience, assuring a sustainable development path to local communities. Following an integrated evolution path balancing ecological conservation with socio-economic development, a local district will result as particularly stable and balanced over time in all its constituting components (environment, society, economy) when operating as a sustainable and resilient system.

Author Contributions: Conceptualization, L.S. and G.Q.; methodology, F.G. and R.V.; software, A.G.M.; validation, J.R.-C.; formal analysis, N.M., A.G.M., and F.G.; investigation, R.V. and N.M.; resources, F.G. and J.R.-C.; data curation, A.G.M.; writing-original draft preparation, L.S. and G.Q.; writing-review and editing, N.M. and J.R.-C.; visualization, R.V.; supervision, A.G.M.; project administration, F.G.; funding acquisition, F.G. All authors have read and agreed to the published version of the manuscript.

Funding: This work received no funding.

Institutional Review Board Statement: Not applicable.

Informed Consent Statement: Not applicable.

Data Availability Statement: Not applicable.

Conflicts of Interest: The authors declare no conflict of interest.

\section{References}

1. Basso, B.; Simone, L.D.; Ferrara, A.; Cammarano, D.; Cafiero, G.; Yeh, M.-L.; Chou, T.-Y. Analysis of Contributing Factors to Desertification and Mitigation Measures in Basilicata Region. Ital. J. Agron. 2010, 5, 33-44. [CrossRef]

2. Briassoulis, H. Policy Integration for Complex Environmental Problems: The Example of Mediterranean Desertification; Routledge: London, UK, 2005.

3. Rodrigo-Comino, J.; López-Vicente, M.; Kumar, V.; Rodríguez-Seijo, A.; Valkó, O.; Rojas, C.; Pourghasemi, H.R.; Salvati, L.; Bakr, N.; Vaudour, E.; et al. Soil Science Challenges in a New Era: A Transdisciplinary Overview of Relevant Topics. Air Soil Water Res. 2020, 13, 1178622120977491. [CrossRef] 
4. Rodrigo-Comino, J.; Senciales, J.M.; Cerdà, A.; Brevik, E.C. The Multidisciplinary Origin of Soil Geography: A Review. Earth-Sci. Rev. 2018, 177, 114-123. [CrossRef]

5. Kosmas, C.; Karamesouti, M.; Kounalaki, K.; Detsis, V.; Vassiliou, P.; Salvati, L. Land Degradation and Long-Term Changes in Agro-Pastoral Systems: An Empirical Analysis of Ecological Resilience in Asteroussia-Crete (Greece). CATENA 2016, 147, 196-204. [CrossRef]

6. Dregne, H.E. Land Degradation in the Drylands. Arid Land Res. Manag. 2002, 16, 99-132. [CrossRef]

7. Mainguet, M. Desertification: Natural Background and Human Mismanagement; Springer: Berlin/Heidelberg, Germany, 1994.

8. Puigdefábregas, J. Ecological Impacts of Global Change on Drylands and Their Implications for Desertification. Land Degrad. Dev. 1998, 393-406. [CrossRef]

9. An, H.; Tang, Z.; Keesstra, S.; Shangguan, Z. Impact of Desertification on Soil and Plant Nutrient Stoichiometry in a Desert Grassland. Sci. Rep. 2019, 9. [CrossRef]

10. Behnke, R.; Mortimore, M. Introduction: The End of Desertification? In The End of Desertification?: Disputing Environmental Change in the Drylands; Behnke, R., Mortimore, M., Eds.; Springer Earth System Sciences; Springer: Berlin/Heidelberg, Germany, 2016; pp. 1-34. ISBN 978-3-642-16014-1.

11. Glantz, M.H. Desertification: Environmental Degradation in And Around Arid Lands, 1st ed.; Taylor \& Francis Ltd.: Abingdon-onThames, UK, 2019; ISBN 978-0-367-02103-0.

12. Norman, L.M. Ecosystem Services of Riparian Restoration: A Review of Rock Detention Structures in the Madrean Archipelago Ecoregion. Air Soil Water Res. 2020, 13, 1178622120946337. [CrossRef]

13. Verón, S.R.; Paruelo, J.M.; Oesterheld, M. Assessing Desertification. J. Arid Environ. 2006, 66, 751-763. [CrossRef]

14. Johnson, D.L.; Lewis, L.A. Land Degradation: Creation and Destruction; Rowman \& Littlefield: Lanham, MD, USA, 2007; ISBN 978-0-7425-1948-0.

15. Verstraete, M.M.; Brink, A.B.; Scholes, R.J.; Beniston, M.; Stafford Smith, M. Climate Change and Desertification: Where Do We Stand, Where Should We Go? Glob. Planet. Chang. 2008, 64, 105-110. [CrossRef]

16. Helldén, U.; Tottrup, C. Regional Desertification: A Global Synthesis. Glob. Planet. Chang. 2008, 64, 169-176. [CrossRef]

17. Abu Hammad, A.; Tumeizi, A. Land Degradation: Socioeconomic and Environmental Causes and Consequences in the Eastern Mediterranean. Land Degrad. Dev. 2012, 23, 216-226. [CrossRef]

18. Barbero-Sierra, C.; Marques, M.J.; Ruíz-Pérez, M. The Case of Urban Sprawl in Spain as an Active and Irreversible Driving Force for Desertification. J. Arid Environ. 2013, 90, 95-102. [CrossRef]

19. Atis, E. Economic Impacts on Cotton Production Due to Land Degradation in the Gediz Delta, Turkey. Land Use Policy 2006, 23, 181-186. [CrossRef]

20. Buttoud, G. Research and Innovation in Sustainable Forestry: Lessons Learnt to Inform the Policy Making Community. Ann. Silvic. Res. 2015, 38, 74-77. [CrossRef]

21. Cimini, D.; Tomao, A.; Mattioli, W.; Barbati, A.; Corona, P. Assessing Impact of Forest Cover Change Dynamics on High Nature Value Farmland in Mediterranean Mountain Landscape. Ann. Silvic. Res. 2013, 37, 29-37. [CrossRef]

22. Colantoni, A.; Allegrini, E.; Boubaker, K.; Longo, L.; Di Giacinto, S.; Biondi, P. New Insights for Renewable Energy Hybrid Photovoltaic/Wind Installations in Tunisia through a Mathematical Model. Energy Convers. Manag. 2013, 75, 398-401. [CrossRef]

23. Corona, P. Forestry Research to Support the Transition towards a Bio-Based Economy. Ann. Silvic. Res. 2015, 38, 37-38. [CrossRef]

24. Corona, P.; Chirici, G.; Marchetti, M. Forest Ecosystem Inventory and Monitoring as a Framework for Terrestrial Natural Renewable Resource Survey Programmes. Plant Biosyst.-An Int. J. Deal. All Asp. Plant Biol. 2002, 136, 69-82. [CrossRef]

25. Ahmadi, B.; Moradkhani, H. Revisiting Hydrological Drought Propagation and Recovery Considering Water Quantity and Quality. Hydrol. Process. 2019, 33, 1492-1505. [CrossRef]

26. Brito, C.; Dinis, L.-T.; Moutinho-Pereira, J.; Correia, C.M. Drought Stress Effects and Olive Tree Acclimation under a Changing Climate. Plants 2019, 8, 232. [CrossRef] [PubMed]

27. Seely, M.; Wöhl, H. Connecting Research to Combating Desertification. Env. Monit. Assess. 2004, 99, 23-32. [CrossRef] [PubMed]

28. Bakr, N.; Weindorf, D.C.; Bahnassy, M.H.; El-Badawi, M.M. Multi-Temporal Assessment of Land Sensitivity to Desertification in a Fragile Agro-Ecosystem: Environmental Indicators. Ecol. Indic. 2012, 15, 271-280. [CrossRef]

29. Portnov, B.A.; Safriel, U.N. Combating Desertification in the Negev: Dryland Agriculture vs. Dryland Urbanization. J. Arid Environ. 2004, 56, 659-680. [CrossRef]

30. Auernheimer, C.; González, G. Repercussions of the national hydrological plan on the Spanish Mediterranean coast (water versus tourism and agriculture). In Local Resources and Global Trades: Environments and Agriculture in the Mediterranean Region; Camarda, D., Grassini, L., Eds.; Options Méditerranéennes: Série A. Séminaires Méditerranéens, 2002; Volume 57, pp. $179-185$.

31. Bimonte, S.; Stabile, A. Land Consumption and Income in Italy: A Case of Inverted EKC. Ecol. Econ. 2017, 131, 36-43. [CrossRef]

32. Le Houérou, H.N. Land Degradation in Mediterranean Europe: Can Agroforestry Be a Part of the Solution? A Prospective Review. Agroforest Syst. 1993, 21, 43-61. [CrossRef]

33. Marchetti, M.; Vizzarri, M.; Lasserre, B.; Sallustio, L.; Tavone, A. Natural Capital and Bioeconomy: Challenges and Opportunities for Forestry. Ann. Silvic. Res. 2015, 38, 62-73. [CrossRef]

34. Palazzo, A.L.; Aristone, O. Peri-Urban Matters. Changing Olive Growing Patterns in Central Italy. Sustainability 2017, 9, 638. [CrossRef] 
35. Rose, A.; Liao, S.-Y. Modeling Regional Economic Resilience to Disasters: A Computable General Equilibrium Analysis of Water Service Disruptions*. J. Reg. Sci. 2005, 45, 75-112. [CrossRef]

36. Tanrivermis, H. Agricultural Land Use Change and Sustainable Use of Land Resources in the Mediterranean Region of Turkey. J. Arid Environ. 2003, 54, 553-564. [CrossRef]

37. Tomao, A.; Secondi, L.; Corona, P.; Carrus, G.; Agrimi, M. Exploring Individuals' Well-Being Visiting Urban and Peri-Urban Green Areas: A Quantile Regression Approach. Agric. Agric. Sci. Procedia 2016, 8, 115-122. [CrossRef]

38. Naude, W. Measuring Vulnerability in Developing Countries: New Analytical Approaches; Routledge: London, UK, 2013; ISBN 978-0-415-84949-4.

39. Elmqvist, T.; Folke, C.; Nyström, M.; Peterson, G.; Bengtsson, J.; Walker, B.; Norberg, J. Response Diversity, Ecosystem Change, and Resilience. Front. Ecol. Environ. 2003, 1, 488-494. [CrossRef]

40. Pendall, R.; Foster, K.A.; Cowell, M. Resilience and Regions: Building Understanding of the Metaphor. Camb. J. Regions. Econ. Soc. 2010, 3, 71-84. [CrossRef]

41. Eaton, R.L.; Hammond, G.P.; Laurie, J. Footprints on the Landscape: An Environmental Appraisal of Urban and Rural Living in the Developed World. Landsc. Urban Plan. 2007, 83, 13-28. [CrossRef]

42. Donovan, S.; Looney, C.; Hanson, T.; Sánchez de León, Y.; Wulfhorst, J.D.; Eigenbrode, S.; Jennings, M.; Johnson-Maynard, J.; Bosque Pérez, N. Reconciling Social and Biological Needs in an Endangered Ecosystem: The Palouse as a Model for Bioregional Planning. Ecol. Soc. 2009, 14. [CrossRef]

43. Alessa, L.L.; Kliskey, A.; Brown, G.; Guida, L. Social-Ecological Hotspots Mapping: A Spatial Approach for Identifying Coupled Social-Ecological Space. Landsc. Urban Plan. 2008, 85, 27-39. [CrossRef]

44. Barkley, D.L.; Henry, M.S.; Bao, S. Identifying "Spread" versus "Backwash" Effects in Regional Economic Areas: A Density Functions Approach. Land Econ. 1996, 72, 336-357. [CrossRef]

45. Berkes, F.; Folke, C.; Colding, J. Linking Social and Ecological Systems: Management Practices and Social Mechanisms for Building Resilience; Cambridge University Press: Cambridge, UK, 2000; ISBN 978-0-521-78562-4.

46. Bojö, J. The Costs of Land Degradation in Sub-Saharan Africa. Ecol. Econ. 1996, 16, 161-173. [CrossRef]

47. Briguglio, L.; Cordina, G.; Farrugia, N.; Vella, S. Economic Vulnerability and Resilience: Concepts and Measurements. Oxf. Dev. Stud. 2009, 37, 229-247. [CrossRef]

48. Bristow, G. Resilient Regions: Re-'place'ing Regional Competitiveness. Camb. J. Reg. Econ. Soc. 2010, 3, 153-167. [CrossRef]

49. Martin, R. Regional Economic Resilience, Hysteresis and Recessionary Shocks. J. Econ. Geogr. 2012, 12, 1-32. [CrossRef]

50. Portugali, J. Complexity Theory as a Link between Space and Place. Environ. Plan. A 2016. [CrossRef]

51. Gunderson, L.H. Panarchy: Understanding Transformations in Human and Natural Systems; Gunderson, L.H., Holling, C.S., Eds.; World Bank: Washington, DC, USA, 2001; ISBN 978-1-55963-857-9.

52. Mohammed, S.; Alsafadi, K.; Talukdar, S.; Kiwan, S.; Hennawi, S.; Alshihabi, O.; Sharaf, M.; Harsanyie, E. Estimation of Soil Erosion Risk in Southern Part of Syria by Using RUSLE Integrating Geo Informatics Approach. Remote Sens. Appl. Soc. Environ. 2020, 20, 100375. [CrossRef]

53. Sendzimir, J.; Reij, C.; Magnuszewski, P. Rebuilding Resilience in the Sahel: Regreening in the Maradi and Zinder Regions of Niger. Ecol. Soc. 2011, 16. [CrossRef]

54. Roggema, R. The Future of Sustainable Urbanism: Society-Based, Complexity-Led, and Landscape-Driven. Sustainability 2017, 9 , 1442. [CrossRef]

55. Quinlan, A.E.; Berbés-Blázquez, M.; Haider, L.J.; Peterson, G.D. Measuring and Assessing Resilience: Broadening Understanding through Multiple Disciplinary Perspectives. J. Appl. Ecol. 2016, 53, 677-687. [CrossRef]

56. Frank, A.K. What Is the Story with Sustainability? A Narrative Analysis of Diverse and Contested Understandings. J. Environ. Stud. Sci. 2017, 7, 310-323. [CrossRef]

57. James, R.F.; Cato, M.S. A Bioregional Economy: A Green and Post-Capitalist Alternative to an Economy of Accumulation. Local Econ. 2014, 29, 173-180. [CrossRef]

58. Jiang, L.; Jiapaer, G.; Bao, A.; Kurban, A.; Guo, H.; Zheng, G.; De Maeyer, P. Monitoring the Long-Term Desertification Process and Assessing the Relative Roles of Its Drivers in Central Asia. Ecol. Indic. 2019, 104, 195-208. [CrossRef]

59. Smiraglia, D.; Ceccarelli, T.; Bajocco, S.; Salvati, L.; Perini, L. Linking Trajectories of Land Change, Land Degradation Processes and Ecosystem Services. Environ. Res. 2016, 147, 590-600. [CrossRef]

60. Reynolds, J.F.; Grainger, A.; Stafford Smith, D.M.; Bastin, G.; Garcia-Barrios, L.; Fernández, R.J.; Janssen, M.A.; Jürgens, N.; Scholes, R.J.; Veldkamp, A.; et al. Scientific Concepts for an Integrated Analysis of Desertification. Land Degrad. Dev. 2011, 22, 166-183. [CrossRef]

61. Torres, L.; Abraham, E.M.; Rubio, C.; Barbero-Sierra, C.; Ruiz-Pérez, M. Desertification Research in Argentina. Land Degrad. Dev. 2015, 26, 433-440. [CrossRef]

62. Johnson, P.-M.; Mayrand, K.; Paquin, M. Governing Global Desertification: Linking Environmental Degradation, Poverty and Participation; Ashgate Publishing, Ltd.: Farnham, UK, 2006; ISBN 978-0-7546-4359-3.

63. Hill, J.; Stellmes, M.; Udelhoven, T.h.; Röder, A.; Sommer, S. Mediterranean Desertification and Land Degradation: Mapping Related Land Use Change Syndromes Based on Satellite Observations. Glob. Planet. Chang. 2008, 64, 146-157. [CrossRef]

64. Briassoulis, H. Governing Desertification in Mediterranean Europe: The Challenge of Environmental Policy Integration in Multi-Level Governance Contexts. Land Degrad. Dev. 2011, 22, 313-325. [CrossRef] 
65. Helldén, U. A Coupled Human-Environment Model for Desertification Simulation and Impact Studies. Glob. Planet. Chang. 2008, 64, 158-168. [CrossRef]

66. Máñez Costa, M.; Moors, E.; Fraser, E.D.G. Socioeconomics, Policy, or Climate Change: What is Driving Vulnerability in Southern Portugal? Ecol. Soc. 2011, 16. [CrossRef]

67. Salvati-Comino, J.; Terol, E.; Mora, G.; Gimenez-Morera, A.; Cerdà, A. Vicia Sativa Roth. Can Reduce Soil and Water Losses in Recently Planted Vineyards (Vitis Vinifera L.). Earth Syst. Environ. 2020. [CrossRef]

68. Panagos, P.; Katsoyiannis, A. Soil Erosion Modelling: The New Challenges as the Result of Policy Developments in Europe. Environ. Res. 2019, 172, 470-474. [CrossRef]

69. Santini, M.; Caccamo, G.; Laurenti, A.; Noce, S.; Valentini, R. A Multi-Component GIS Framework for Desertification Risk Assessment by an Integrated Index. Appl. Geogr. 2010, 30, 394-415. [CrossRef]

70. Moreda, T. Contesting Conventional Wisdom on the Links between Land Tenure Security and Land Degradation: Evidence from Ethiopia. Land Use Policy 2018, 77, 75-83. [CrossRef]

71. Meerow, S.; Newell, J.P.; Stults, M. Defining Urban Resilience: A Review. Landsc. Urban Plan. 2016, 147, 38-49. [CrossRef]

72. Monarca, D.; Cecchini, M.; Guerrieri, M.; Colantoni, A. Conventional and Alternative Use of Biomasses Derived by Hazelnut Cultivation and Processing. Acta Hortic. 2009, 627-634. [CrossRef]

73. Salinas, C.X.; Mendieta, J. Mitigation and Adaptation Investments for Desertification and Climate Change: An Assessment of the Socioeconomic Return. Mitig. Adapt. Strateg. Glob. Chang. 2013, 18, 659-672. [CrossRef]

74. Cao, S.; Liu, Y.; Yu, Z. China's Successes at Combating Desertification Provide Roadmap for Other Nations. Environ. Sci. Policy Sustain. Dev. 2018, 60, 16-24. [CrossRef]

75. Reynolds, J.F.; Smith, D.M.S.; Lambin, E.F.; Turner, B.L.; Mortimore, M.; Batterbury, S.P.J.; Downing, T.E.; Dowlatabadi, H.; Fernandez, R.J.; Herrick, J.E.; et al. Global Desertification: Building a Science for Dryland Development. Science 2007, 316, 847-851. [CrossRef] [PubMed]

76. Scholes, R.J. Syndromes of Dryland Degradation in Southern Africa. Afr. J. Range Forage Sci. 2009, 26, 113-125. [CrossRef]

77. Darkoh, M.B.K. The Nature, Causes and Consequences of Desertification in the Drylands of Africa. Land Degrad. Dev. 1998, 9 , 1-20. [CrossRef]

78. Kessler, C.A.; Stroosnijder, L. Land Degradation Assessment by Farmers in Bolivian Mountain Valleys. Land Degrad. Dev. 2006, 17, 235-248. [CrossRef]

79. Bajocco, S.; De Angelis, A.; Salvati, L. A Satellite-Based Green Index as a Proxy for Vegetation Cover Quality in a Mediterranean Region. Ecol. Indic. 2012, 23, 578-587. [CrossRef]

80. Mortimore, M.; Turner, B. Does the Sahelian Smallholder's Management of Woodland, Farm Trees, Rangeland Support the Hypothesis of Human-Induced Desertification? J. Arid Environ. 2005, 63, 567-595. [CrossRef]

81. Kishk, M.A. Combating Desertification, Is It Always Possible? The Case of Small Egyptian Farmers. GeoJournal 1993, 31, 77-84. [CrossRef]

82. Karamesouti, M.; Detsis, V.; Kounalaki, A.; Vasiliou, P.; Salvati, L.; Kosmas, C. Land-Use and Land Degradation Processes Affecting Soil Resources: Evidence from a Traditional Mediterranean Cropland (Greece). CATENA 2015, 132, 45-55. [CrossRef]

83. Salvati, L.; Zitti, M. Regional Convergence of Environmental Variables: Empirical Evidences from Land Degradation. Ecol. Econ. 2008, 68, 162-168. [CrossRef]

84. Nkonya, E.; Mirzabaev, A.; von Braun, J. Economics of Land Degradation and Improvement: An Introduction and Overview. In Economics of Land Degradation and Improvement-A Global Assessment for Sustainable Development; Nkonya, E., Mirzabaev, A., von Braun, J., Eds.; Springer International Publishing: Cham, Switzerland, 2016; pp. 1-14. ISBN 978-3-319-19168-3.

85. Prăvălie, R.; Patriche, C.; Săvulescu, I.; Sîrodoev, I.; Bandoc, G.; Sfîcă, L. Spatial Assessment of Land Sensitivity to Degradation across Romania. A Quantitative Approach Based on the Modified MEDALUS Methodology. CATENA 2020, 187, 104407. [CrossRef]

86. Xu, D.; Li, C.; Zhuang, D.; Pan, J. Assessment of the Relative Role of Climate Change and Human Activities in Desertification: A Review. J. Geogr. Sci. 2011, 21, 926. [CrossRef]

87. Varghese, N.; Singh, N.P. Linkages between Land Use Changes, Desertification and Human Development in the Thar Desert Region of India. Land Use Policy 2016, 51, 18-25. [CrossRef]

88. Karamesouti, M.; Panagos, P.; Kosmas, C. Model-Based Spatio-Temporal Analysis of Land Desertification Risk in Greece. CATENA 2018, 167, 266-275. [CrossRef]

89. Chelli, F.M.; Ciommi, M.; Emili, A.; Gigliarano, C.; Taralli, S. Assessing the Equitable and Sustainable Well-Being of the Italian Provinces. Int. J. Unc. Fuzz. Knowl. Based Syst. 2016, 24, 39-62. [CrossRef]

90. Keesstra, S.; Mol, G.; De Leeuw, J.; Okx, J.; Molenaar, C.; De Cleen, M.; Visser, S. Soil-Related Sustainable Development Goals: Four Concepts to Make Land Degradation Neutrality and Restoration Work. Land 2018, 7, 133. [CrossRef]

91. Tal, A. The Implications of Environmental Trading Mechanisms on a Future Zero Net Land Degradation Protocol. J. Arid Environ. 2015, 112, 25-32. [CrossRef]

92. Requier-Desjardins, M.; Adhikari, B.; Sperlich, S. Some Notes on the Economic Assessment of Land Degradation. Land Degrad. Dev. 2011, 22, 285-298. [CrossRef] 
93. Sommer, S.; Zucca, C.; Grainger, A.; Cherlet, M.; Zougmore, R.; Sokona, Y.; Hill, J.; Della Peruta, R.; Roehrig, J.; Wang, G. Application of Indicator Systems for Monitoring and Assessment of Desertification from National to Global Scales. Land Degrad. Dev. 2011, 22, 184-197. [CrossRef]

94. Polasky, S.; Segerson, K. Integrating Ecology and Economics in the Study of Ecosystem Services: Some Lessons Learned. Annu. Rev. Resour. Econ. 2009, 1, 409-434. [CrossRef]

95. Stocking, M.A.; Murnaghan, N. A Handbook for the Field Assessment of Land Degradation; Earthscan Publications Ltd.: London, UK, 2001.

96. Fernández, R.J. Do Humans Create Deserts? Trends Ecol. Evol. 2002, 17, 6-7. [CrossRef]

97. Salvati, L.; Zitti, M.; Perini, L. Fifty Years on: Long-Term Patterns of Land Sensitivity to Desertification in Italy. Land Degrad. Dev. 2016, 27, 97-107. [CrossRef]

98. Ferrara, A.; Kosmas, C.; Salvati, L.; Padula, A.; Mancino, G.; Nolè, A. Updating the MEDALUS-ESA Framework for Worldwide Land Degradation and Desertification Assessment. Land Degrad. Dev. 2020, 31, 1593-1607. [CrossRef]

99. Fisher, B.; Turner, R.K.; Morling, P. Defining and Classifying Ecosystem Services for Decision Making. Ecol. Econ. 2009, 68, 643-653. [CrossRef]

100. Gibbs, H.K.; Salmon, J.M. Mapping the World's Degraded Lands. Appl. Geogr. 2015, 57, 12-21. [CrossRef]

101. Geist, H. The Causes and Progression of Desertification; Aldershot England: Burlington, VT, USA, 2005; ISBN 978-0-7546-4323-4.

102. Requier-Desjardins, M. The Economic Costs of Desertification: A First Survey of Some Cases in Africa. Int. J. Sustain. Dev. 2006, 9 , 199-209. [CrossRef]

103. Walpole, S.; Sinden, J.; Yapp, T. Land Quality as an Input to Production: The Case of Land Degradation and Agricultural Output. Econ. Anal. Policy 1996, 26, 185-207. [CrossRef]

104. Baumber, A.; Berry, E.; Metternicht, G. Synergies between Land Degradation Neutrality Goals and Existing Market-Based Instruments. Environ. Sci. Policy 2019, 94, 174-181. [CrossRef]

105. Sigalos, G.; Loukaidi, V.; Dasaklis, S.; Drakopoulou, P.; Salvati, L.; Ruiz, P.S.; Mavrakis, A. Soil Erosion and Degradation in a Rapidly Expanding Industrial Area of Eastern Mediterranean Basin (Thriasio Plain, Greece). Nat. Hazards 2016, 82, 2187-2200. [CrossRef]

106. Martin, R.; Sunley, P. On the Notion of Regional Economic Resilience: Conceptualization and Explanation. J. Econ. Geogr. 2015, 15, 1-42. [CrossRef]

107. van Oudenhoven, F.J.W.; Mijatović, D.; Eyzaguirre, P.B. Social-ecological Indicators of Resilience in Agrarian and Natural Landscapes. Manag. Environ. Qual. An Int. J. 2011, 22, 154-173. [CrossRef]

108. Wilson, G.A.; Juntti, M. Unravelling Desertification; Geoff, A., Wilson, M.J., Eds.; Wageningen Academic Publishers: Wageningen, The Netherlands, 2005; ISBN 978-90-76998-42-8.

109. Modica, M.; Reggiani, A. Spatial Economic Resilience: Overview and Perspectives. Netw. Spat. Econ. 2015, 15, 211-233. [CrossRef]

110. Briassoulis, H. The Institutional Complexity of Environmental Policy and Planning Problems: The Example of Mediterranean Desertification. J. Environ. Plan. Manag. 2004, 47, 115-135. [CrossRef]

111. Ferrara, A.; Kelly, C.; Wilson, G.A.; Nolè, A.; Mancino, G.; Bajocco, S.; Salvati, L. Shaping the Role of "fast" and "Slow" Drivers of Change in Forest-Shrubland Socio-Ecological Systems. J. Environ. Manage. 2016, 169, 155-166. [CrossRef]

112. Zolli, A.; Healy, A.M. Resilience: Why Things Bounce Back; Hachette UK: London, UK, 2013; ISBN 978-1-4516-8381-3.

113. Haines-Young, R.; Potschin, M. The links between biodiversity, ecosystem services and human well-being. In Ecosystem Ecology: A New Synthesis; Frid, C.L.J., Raffaelli, D.G., Eds.; Ecological Reviews; Cambridge University Press: Cambridge, UK, 2010; pp. 110-139. ISBN 978-0-521-51349-4.

114. Petrosillo, I.; Zaccarelli, N.; Zurlini, G. Multi-Scale Vulnerability of Natural Capital in a Panarchy of Social-Ecological Landscapes. Ecol. Complex. 2010, 7, 359-367. [CrossRef]

115. Chelli, F.; Rosti, L. Age and Gender Differences in Italian Workers' Mobility. Int. J. Manpow. 2002, 23, 313-325. [CrossRef]

116. Rosti, L.; Yamaguchi, C.; Castagnetti, C. Educational Performance as Signalling Device: Evidence from Italy. Econ. Bull. 2005, 9, 1-7.

117. Gigliarano, C.; Chelli, F.M. Measuring Inter-Temporal Intragenerational Mobility: An Application to the Italian Labour Market. Qual. Quant. 2016, 50, 89-102. [CrossRef]

118. Chelli, F.; Gigliarano, C.; Mattioli, E. The Impact of Inflation on Heterogeneous Groups of Households: An Application to Italy. Econ. Bull. 2009, 29, 1276-1295.

119. Sutton, P.C.; Anderson, S.J.; Costanza, R.; Kubiszewski, I. The Ecological Economics of Land Degradation: Impacts on Ecosystem Service Values. Ecol. Econ. 2016, 129, 182-192. [CrossRef] 